Scientific Journal Warsaw University of Life Sciences - SGGW

Problems of World Agriculture volume 17 (XXXII), number 4, 2017: 302-315

DOI: 10.22630/PRS.2017.17.4.106

\author{
Ewa Wasilewska $^{1}$ \\ Warsaw University of Life Sciences - SGGW
}

\title{
Demographical Ageing of the EU Member States' Societies
}

\begin{abstract}
A spatial differentiation of the level of demographical senility was illustrated in the study, along with determination of dynamics of the European Union Member States ageing process (EU 27). The research period included years 1996-2016. The measures of demographical senility were used in the static and dynamical aspect. Country grouping due to the level of demographical senility advancement was performed based on statistical measures. A significant differentiation of the demographical senility level and population ageing process in the spatial system were found. The highest degree of demographical senility advancement was observed in the countries of "the old" Union but the greatest dynamics of this process was shown in the case of new Member States, including Poland and Baltic States.
\end{abstract}

Key words: population ageing, demographical ageing, measures of demographical senility, European Union Member States

JEL Classification: J11, J14, N34

\section{Introduction}

The $20^{\text {th }}$ century and the beginning of this century is a period of very important population changes in Europe and around the world the dynamics and direction of which evoke many concerns (Urbaniak, 2015). Those changes lead to the phenomenon of society ageing, i.e. constantly increasing share of elderly people in the population, and the problem affects societies all over the world, in particular highly developed countries, including European Union Member States. A lot of modern day European nations are coping with the growing proportion of elderly citizens (Italy, Nordic and Balkan nations are some notable examples). These demographic changes have brought several important burden in different areas of social life. The first and most concerning one is the fact that most domestic-driven European labor forces are gradually shrinking. Long term and continuing shortages of labor are particularly visible in some areas such as professional medical and nursing staff (Jakovljevic, 2015).

The reasons for society ageing are sought in civilizational, social and cultural changes (Blaikie, 1999; Coulmas, 2007). This long term evolution was encircled with decreasing female fertility, improved early childhood survival, falling mortality rates and extended longevity (Jakovljevic, 2015). An important factor that accelerates the society ageing process is also the negative migration balance (Buchanan, 2010), especially if those who emigrate are people of young and average age (Rakowska, 2016).

Ageing has not only a demographical dimension, but also influences various spheres of social-economic life, in particular the labour market, social security, public services,

${ }^{1} \mathrm{PhD}$, Department of Agricultural Economics and International Economic Relations, Faculty of Economic Sciences WULS - SGGW, ul. Nowoursynowska 166,02-787 Warszawa, e-mail: ewa_wasilewska@sggw.pl, https://orcid.org/0000-0001-9065-5526 
consumption, public expenses, including expenses for retirement-pension purposes (Ogura, Jakovljevic, 2014). That is why the issue of changes of population condition and structure is extremely important and it must be taken into consideration in the national socialeconomic policy (Kłos, Russel, 2016).

The aim of the study is to determine the spatial differentiation of the level of demographical senility as well as to determine the dynamics of society ageing in the European Union Member States (EU 27)2. The static analysis was conducted for years 1996 and 2016, and the dynamic analysis for the period of 1996-2016. The source material was composed of data published by the Statistical Office of the European Union - Eurostat (Eurostat, 2017).

\section{Research method}

The primary issue in the research of demographical ageing is to point out the lower margin of individual senility from the level of which the human individual should be qualified as an old one, i.e. "the threshold of senility". In the subject-matter literature, the "threshold of senility" is usually considered to be the metrical age of 60 or 65 . Currently, due to extension of life time, the majority of researchers are in favour of adoption of the "threshold of senility" at the level of 65 years - in accordance with the concept proposed by the United Nations (Król, 2014). However, it is worth mentioning that this margin is conventional and in the future, due to expected extension of the average life, it time will surely be changed (Gierańczyk, Sadoch, 2016).

Studies regarding population aging can be conducted both in a statistic and dynamic system. An analysis of the phenomenon in the statistical system aims to determine the advancement of the demographical senility within a given territory in a specific period of time. On the other hand, research carried out in the dynamic system leads to determination of changes in this scope (Kurek, 2008).

The following quantitative characteristics were used to evaluate the demographical senility advancement degree in statistical terms (at the given moment $t$ ) (Cieślak, 1992; Kurek, 2008; Kurkiewicz, 2010):

1. The old-age rate $(O A R)$ determining the share of population included in the elderly age population in the general number of population. Adopting 65 years as the threshold of senility, this measure is expressed as follows:

$$
O A R=\frac{P_{65+}}{P} \cdot 100 \%
$$

where:

$P_{65+}$ - population at the age of 65 or older at the moment $t$,

$P$ - general population at the moment $t$.

\footnotetext{
2 Since 1st July 2013 European Union has 28 member states. Only 27 EU countries have been researched in the paper. Croatia is excluded from research, because necessary data for Croatia were not available due to the fact that it's the newest EU member state.
} 
The structure ratio $O A R$ is determined as senility rate and it indicates the percentage of the elderly population in the general population.

The scale of demographical senility is developed based on the senility rate. Contemporarily, the modified UN scale is applied for the purpose of measurement of the degree of population ageing process advancement according to which the share of population at the age of 65 or more $(O A R)$ indicates the degree of population ageing process advancement in the following manner (Jurek, 2012):
below $4 \%$ - young population,
from $4 \%$ to $7 \%$ - mature population,
from $7 \%$ to $14 \%$ - ageing population,
from $14 \%$ to $21 \%$ - old population,
over $21 \% \quad$ - hyper-old (venerable) population.

2. The venerable senility rate $(V S R)$ expressing the share of the population at the age of 80 or more in the general number of population:

$$
V S R=\frac{P_{80+}}{P} \cdot 100 \%
$$

where:

$P_{80+}-$ population at the age of 80 and more at the moment $t$,

$P \quad-$ general population at the moment $t$.

3. The double ageing ratio $(D A R)$ determining the share of the oldest population (at the age of 85 or more) in the population of the elderly (at the age of 65 or more):

$$
D A R=\frac{P_{85+}}{P_{65+}} \cdot 100 \%
$$

where:

$P_{85+}-$ population at the age of 85 of more at the moment $t$,

$P_{65+}-$ population at the age of 65 or more at the moment $t$.

4. The ageing index $(A I)$, also known as the dependency ratio is established as a quotient of the number of people at the age of 65 or more and the number of children and teenagers at the age of $0-14$ :

$$
A I=\frac{P_{65+}}{P_{0-14}} \cdot 100
$$

where:

$P_{65+}$ - population at the age of 65 or older at the moment $t$,

$P_{0-14}$ - population at the age between 0-14 at the moment $t$.

The ageing index $A I$ determines the dependency of the youngest group (0-14 year-old) and the group of the elderly (aged 65 and older). Adopting conventionally the population of the elderly as the population of "grandparents", and the population of the youngest persons as the population of "grandchildren", the ageing index is interpreted as the number of 
"grandparents" corresponding to 100 "grandchildren". The higher the value of the ageing index $A I$ is, the older the society is, because a higher number of the elderly population corresponds to a given number of the youngest persons. A proper population demographical senility starts if the age group 0-14 becomes less numerous than the group $65+$, i.e. when the ageing index (AI) values are higher than 100 (Kowaleski, 2011).

In order to create a ranking of the European Union Member States from the point of view of demographic senility advancement, the aggregated measure constructed using the rank method was employed (Kowaleski, Majdzińska, 2012; Malina, Wanat, 1995; Panek, Zwierzchowski, 2013). The essence of this measure is "averaging" of places taken by particular countries in the rankings created on the basis of previously presented senility measures (old-age rate, venerable senility ratio, double ageing ratio and ageing index). At the beginning, separate rankings were established based on the determined measures. The ranking was decremental which means that the country with the highest value of the given measure took the first place in the ranking ( $\operatorname{rank} n$ ), and the country with the lowest value the last place (rank 1). In each consecutive year the arithmetic mean $\bar{r}_{i}$ of the ranks allocated to each country was determined due to all examined measures of senility, according to the following formula:

$$
\bar{r}_{i}=\frac{1}{m} \sum_{j=1}^{m} r_{i j} \quad(i=1, \ldots, n)
$$

where:

$r_{i j}$ - rank given to $i^{\text {th }}$ country due to $j^{\text {th }}$ measure of senility,

$m$ - number of examined senility measures.

Such a calculated rank mean is the aggregated measure that was employed to order the countries in terms of demographic senility level expressed with multiple measures. The higher value of the aggregated measure $\bar{r}_{i}$, the higher position in the ranking the country has from the point of view of senility advancement.

The constructed aggregated measure was also the basis for division of the analysed countries into groups characterised by the similarity of the level of demographic old age. Having ordered the countries according to the adopted criterion, using the value of the arithmetic mean and standard deviation of the aggregated measure, they were divided into four groups in the following manner (Malina, 2004):

group I: when $\overline{r_{i}} \in\left(\bar{r}+s ; r_{\max }\right] \quad$ - the oldest group,

group II: when $\overline{r_{i}} \in(\bar{r} ; \bar{r}+s]$,

group III: when $\overline{r_{i}} \in(\bar{r}-s ; \bar{r}]$,

group IV: when $\overline{r_{i}} \in\left[r_{\min } ; \bar{r}-s\right] \quad$ - the youngest group,

where:

$\bar{r}$ - arithmetic mean of the aggregated measure $\overline{r_{i}}$,

$s$ - standard deviation of the aggregated measure $\overline{r_{i}}$,

$r_{\min }$ - the lowest value of the aggregated measure $\bar{r}_{i}$,

$r_{\max }$ - the highest value of the aggregated measure $\bar{r}_{i}$. 
For the purpose of assessment of the population ageing process advancement in dynamic approach (in a specific period of time), the ageing rate $(A R)$ was employed which is based on the point differences between the share of young and old population (Dlugosz, 1998), expressed with the following formula:

$$
A R=\left[S_{0-14, t}-S_{0-14, t+n}\right]+\left[S_{65+, t+n}-S_{65+, t}\right]
$$

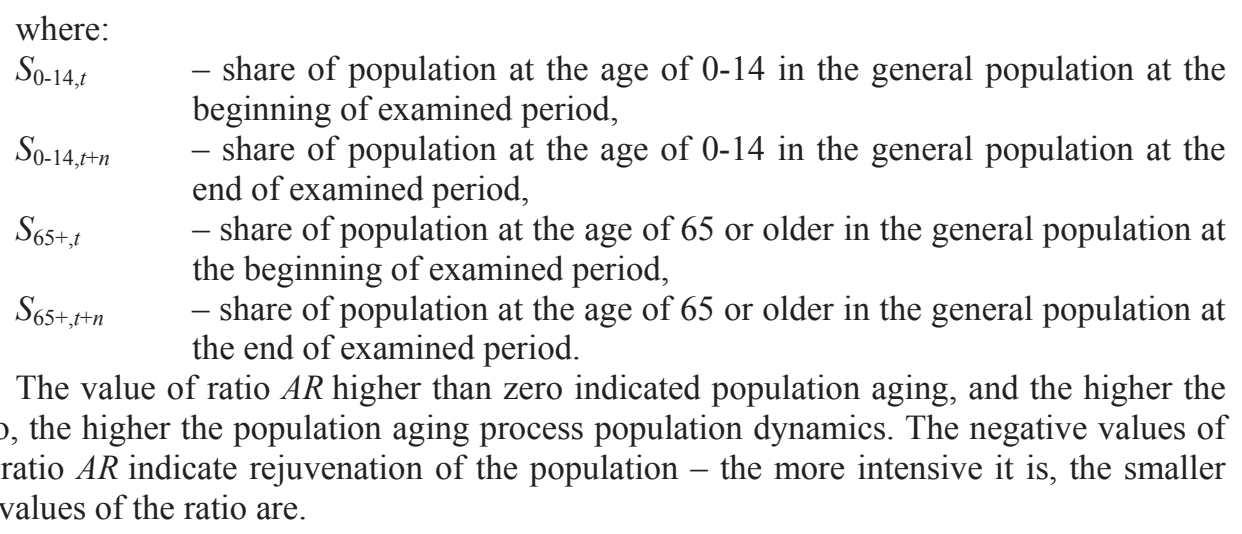

\section{Research results}

In the period 1996-2016 the number of residents of the European Union systematically increased and in 2016 it was 506 million residents in 27 EU Member States (Eurostat, 2017). The overall size of the population is projected to be slightly larger by 2070 than in 2016. The EU population is projected to increase by about 3.5\% between 2016 and 2040 when it will peak, to then remain stable until 2050 and to thereafter decline to 520 million in 2070. While the total EU population will increase by $1.8 \%$ over $2016-2070$, there are wide differences in population trends across Member States, with the population increasing in half of the EU countries and falling in the other half (The 2018 Ageing Report, 2017). These population expansions came dominantly at the expenses of geopolitical expansions and positive net migration into the labor-attractive EU countries.

The growth of the general population is accompanied by the growth of the number of people belonging to the oldest age group with simultaneous decrease of the number of persons aged between 0-14. Within the period of twenty years (1996-2016), the general population $27 \mathrm{EU}$ increased by $5.8 \%$, whereas the increase of number of persons aged 65 and older was $36.0 \%$ and the drop in the number of the youngest persons ( $0-14$ years old) was $8.8 \%$. Corresponding changes of the population age structure were also noted in the examined period. The share of persons aged 65 and older increased by 4.3 p.p. (to $19.2 \%$ in 2016), with concurrent decrease of the share of the youngest people by 2.5 p.p. (to $15.6 \%$ in 2016) - fig.1. The observed changes reflect the on-going demographic transformations. Low fertility rate and extension of the average life span caused an increase in the number of the older persons and their share in the general population, thus resulting in society ageing. 


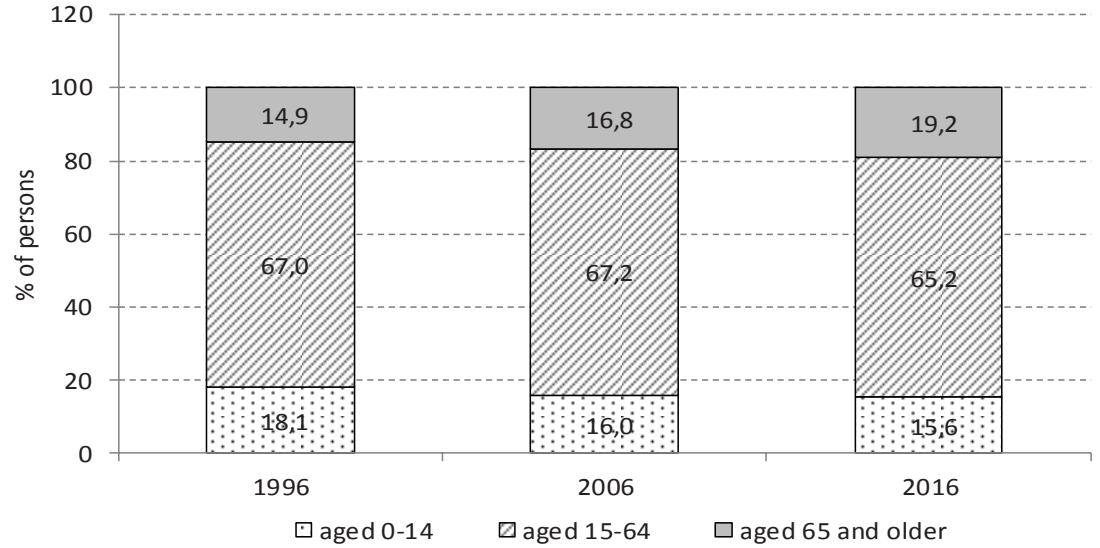

Fig. 1. Structure of population of the European Union (EU 27) in years 1996-2016 according to age groups Source: own study on the basis of Eurostat data.

The share of people at the age of $65+$ in the general population (old-age rate) in the particular countries is illustrated in fig. 2. Although in 1996 the share of persons aged 65+ fell within the range from $10.9 \%$ in Slovakia to $17.5 \%$ in Sweden and reached the average of $14.9 \%$ in the EU, the same share increased significantly in all countries and reached $19.2 \%$ in 2016 . The share of people at the age of $65+$ in the general population increased in this period by 3.5 p.p., and in Sweden by 2.3 p.p. The most distressing situation from the point of view of the pace of growth of the old-age rate was observed in Malta where this factor increased in 1996-2016 by over 7.7 p.p. In 2016 the lowest level of the old-age rate was observed in Ireland (13.2\%), Luxemburg (14.2\%) and Slovakia (14.4\%), and the highest - in Italy (22.0\%), Greece $(21.3 \%)$ and Germany $(21.1 \%)$. In Poland, the share of people aged $65+$ came closer to the level of $16 \%$ in 2016.

Referring to the modified UN scale used currently for the purpose of assessment of the demographic old-age rate advancement degree, it must be stated that in 199612 member states of the current EU could be included in the ageing group (old-age rate in the range of $7 \%-14 \%$ ), whereas other countries - in the old country group (old-age rate in the range $14 \%-21 \%$ ). Only 20 years later, the ageing country group included only 1 country (Ireland), whereas the 3 oldest countries formed a hyper-old country group (old-age rate over $21 \%$ ). Such tendencies indicate a very quickly advancing ageing process in the European Union Member States. It means a very significant growth of the old-age dependency ratio regarding people in the post-production age.

The share of the oldest people i.e. at the age of 80 or older, increased in the analysed period of 1996-2016 in the entire Union as well as in the particular Member States. It is expressed by the ratio of venerable senility (fig. 3). This share in the Member States of the current EU was $3.5 \%$ on average, and in the period of twenty years it increased by over $50 \%$ and in was 5.4\% in 2016. This means that in 2016 almost every eighteenth EU resident was at the age of 80 or older. The following countries were included in 1996 among the countries characterised with the highest percentage of the oldest people $(80+)$ : Sweden (4.7\%), Italy (4.1\%) and Germany, France and Great Britain (4.0\%), and in 2016 - 
Italy (6.7\%), Greece (6.5\%) and Spain (6.0\%). The lowest percentage of people over 80 years of age was noted in 1996 in Romania, Slovakia Poland (2.1\%) and Malta (2.2\%), and in 2016 - in Ireland (3.1\%), Slovakia (3.2\%) and Cyprus (3.3\%).

a)

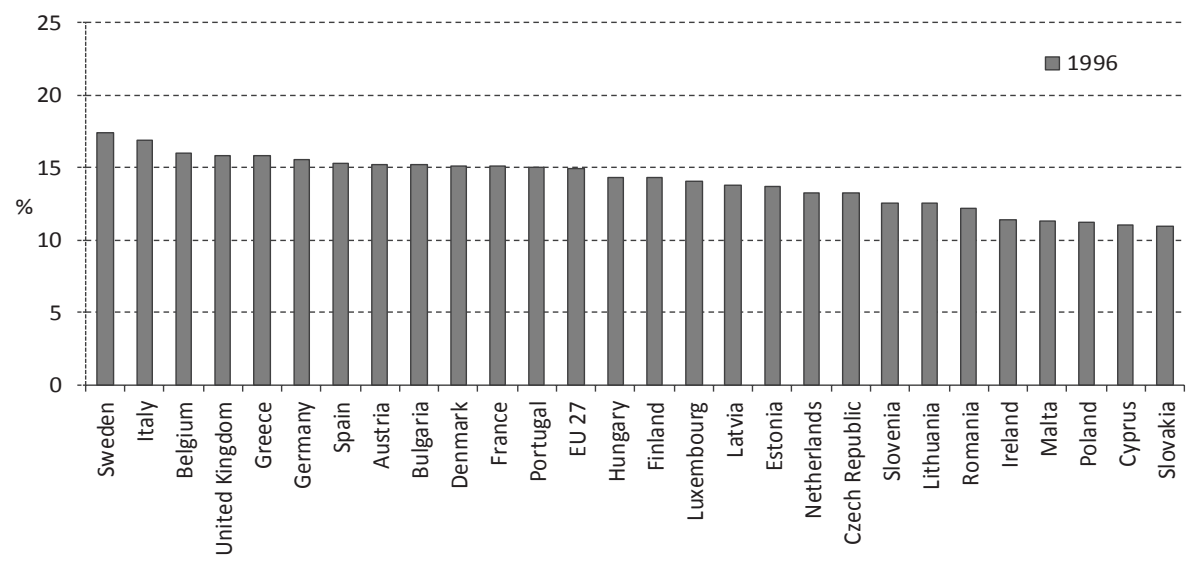

b)

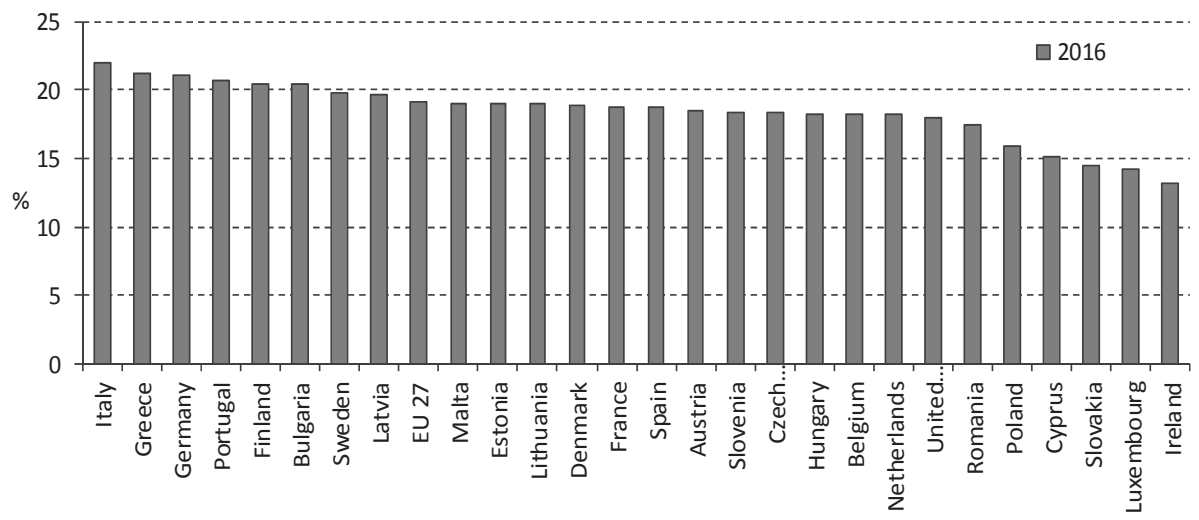

Fig. 2. The old-age rate $O A R$ (percentage of persons at the age of 65+) in the EU countries in 1996 and 2016 Source: own study on the basis of Eurostat data.

Subpopulation of the elderly people (at the age of 65 or older) is characterized with a different age structure in the particular countries. What is particularly important from the point of view of shaping of social and economic policy of the state is the share of the elderly people (at the age of 85 and older) in this subpopulation. There should be different solutions implemented if the dominant persons among the elderly are people at a venerable age, and different ones if the dominant people still belong in the group of professionally active persons (Gierańczyk, Sadoch, 2016). The share of the eldest persons (85+) in the subpopulation of the elderly (65+) is expressed by the double ageing ratio (fig. 4). This share fell in the range from 5.4\% (Bulgaria) to $12.6 \%$ (France), reaching the value of $10.1 \%$ on average for the current UE Member States. In the period between 1996-2016, the double 
ageing ration increased by 3.4 percent point on average and in 2016 it reached $13.4 \%$ which means that almost every seventh person among the elderly is at the venerable age $(85+)$. The highest value of the double ageing ratio in 2016 was noted in France (16.1\%), Spain $(15.6 \%)$ and Italy $(14.9 \%)$, and the lowest - in Bulgaria (8.8\%), Cyprus and Malta $(9.3 \%)$. The Observed tendencies show that along with the growth of the old-age rate in the society, the share of the venerable persons increases in the subpopulation of the elderly.

a)

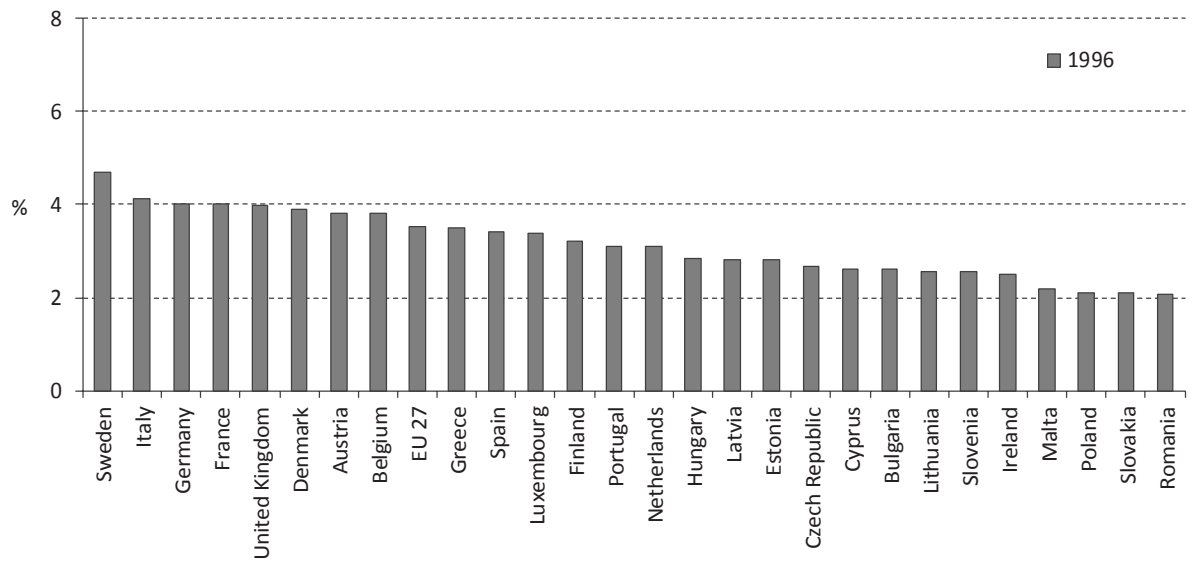

b)

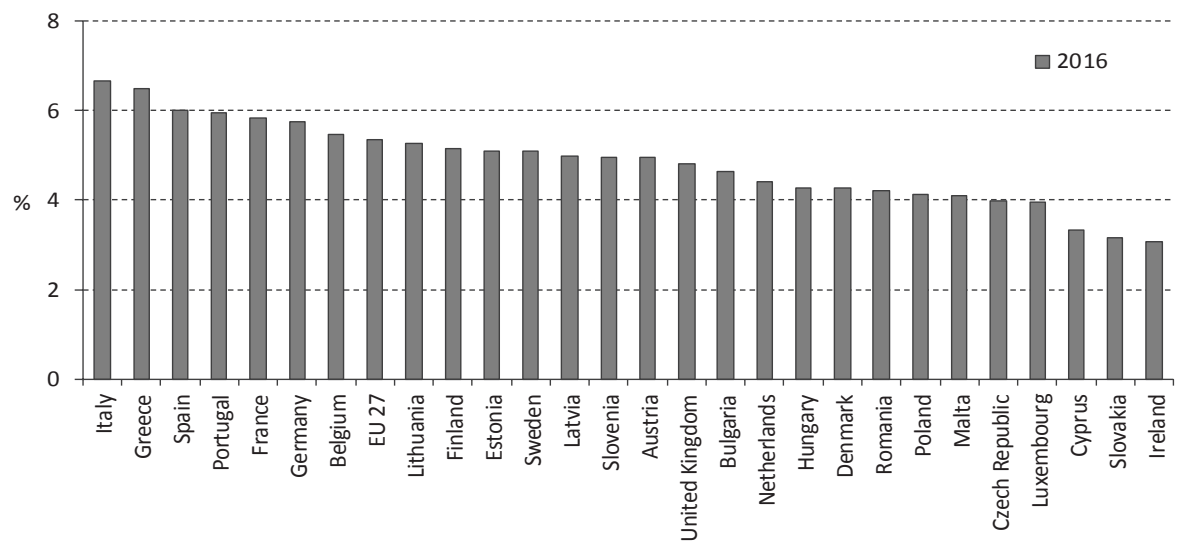

Fig. 3. The venerable senility ratio VSR (percentage of persons at the age of 80+) in the EU Member States in 1996 and 2016

Source: own study on the basis of Eurostat data. 
a)

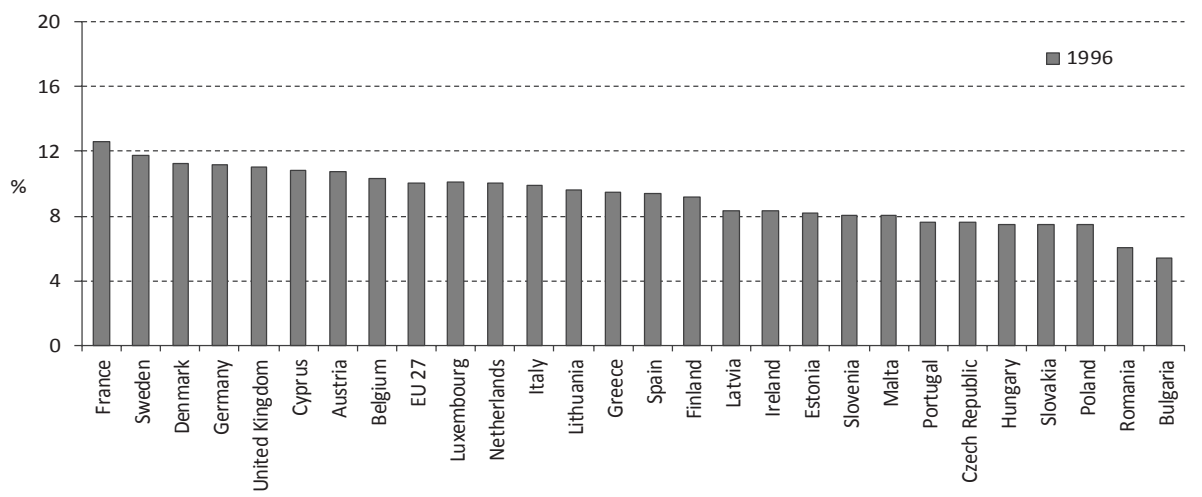

b)

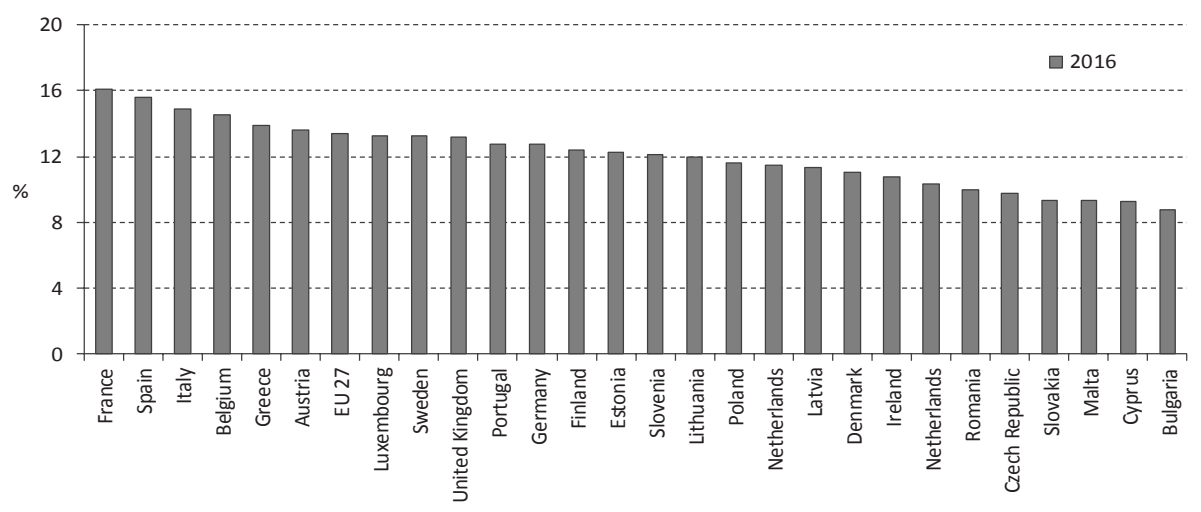

Fig. 4. The double ageing ratio $D A R$ (share of persons at the age of $85+$ in the subpopulation of people at the age of 65+) in the EU Member States in 1996 and 2016

Source: own study on the basis of Eurostat data.

The demographical ageing process cannot be considered only in relation to the elderly persons. A more comprehensive image of the demographical situation is expressed by taking into consideration the share of children and teenagers in the population. The ageing index $(A I)$ based on the relation between the number of the old people (aged 65 and older) and the group of the youngest persons (aged 0-14) indicates a worryingly high ageing process advancement degree in the population of the EU Member States (fig. 5). In 1996 the ageing index was 82.4 on average for the current EU Member States, and it exceeded the value of 100 only in Italy (115.5), but in 2016 this index was higher than 100 in most Member States, reaching the average level of 122.9 in the European Union. It means that the majority of EU Member States in 2016 the number of elderly people (aged 65 and older) exceeded the number of children and teenagers at the age between $0-14$. The alarmingly high demographic old-age rate was recorded in 2016 in Italy (161.4) and in Germany (159.0), indicating a high dependency ratio of the youngest age group and the group of the elderly $(65+)$ in those countries. It should be emphasized that in 2016 in only 
four out of all EU Member States the number of children and youth was higher than the number of the elderly persons (65+). Those countries included: Ireland (60.2), Luxemburg (86.4), Cyprus (91.9) and Slovakia (94.2). Referring to the ageing index, a population is deemed old when the measure exceeds the value of 100 . Therefore, in 2016, the majority of UE Member States (85\%) can be deemed demographically old.

a)

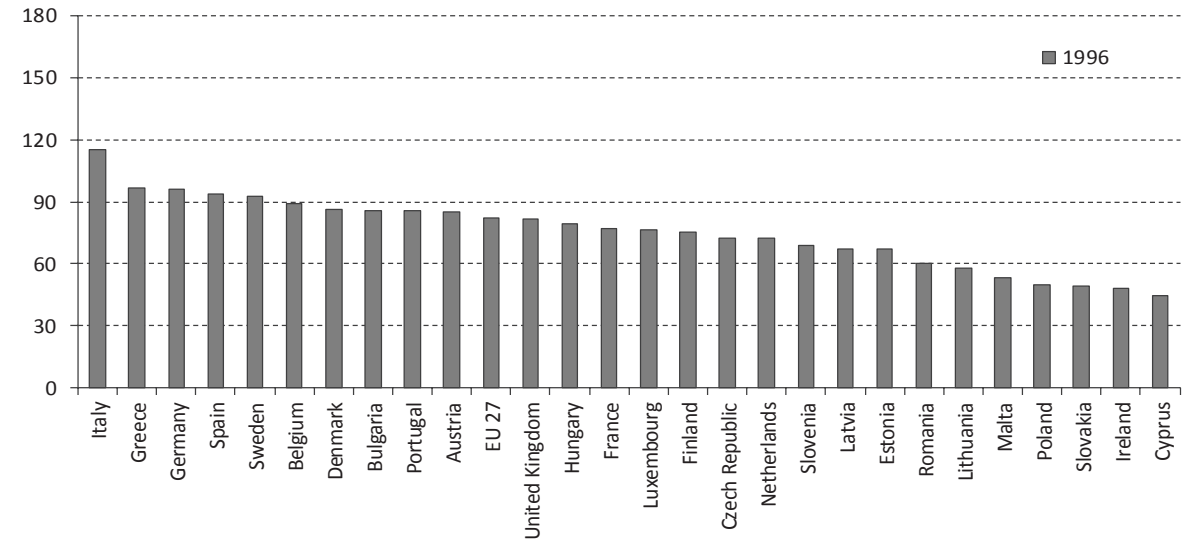

b)

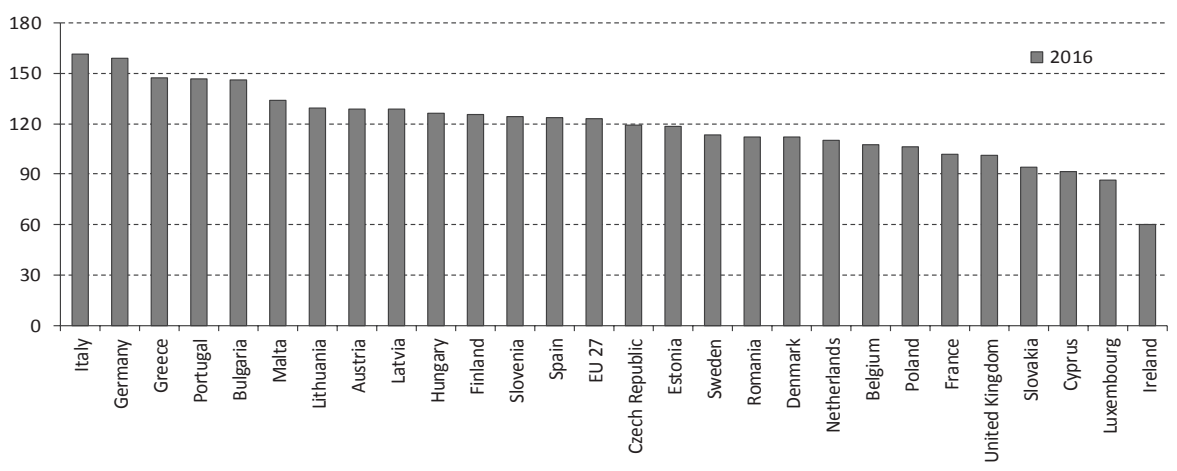

Fig. 5. The ageing index $A I$ (number of persons at the age of $65+$ per 100 people aged between $0-14$ ) in the EU Member States in 1996 and 2016

Source: own study on the basis of Eurostat data.

The presented measures of demographical senility (old-age ratio, venerable senility ratio, double aging ratio and ageing index) allowed for creation of a ranking of countries from the point of view of all analysed measures. Two separate rankings of demographical senility of the EU Member States were prepared for the compared years 1996 and 2016 using the aggregated measure (5). In the next year, on the basis of prepared rankings, the countries were divided into 4 groups characterized by the similarity of the senility level (table 1). The rankings were constructed according to the decreasing value of aggregated 


\section{E. Wasilewska}

measure, therefore the oldest countries were classified in group I and the youngest countries in group IV, respectively.

Table 1. Ranking of countries according to the level of demographical senility in 1996 and 2016

\begin{tabular}{|c|c|c|c|c|}
\hline \multirow[b]{2}{*}{ Group } & \multicolumn{2}{|c|}{1999} & \multicolumn{2}{|c|}{2016} \\
\hline & Country & $\begin{array}{c}\text { Aggregated } \\
\text { measure value }\end{array}$ & Country & $\begin{array}{l}\text { Aggregated } \\
\text { measure value }\end{array}$ \\
\hline \multirow{6}{*}{$\begin{array}{c}\text { I } \\
\text { the oldest countries }\end{array}$} & Sweden & 25.8 & Italy & 26.5 \\
\hline & Germany & 24.0 & Greece & 25.0 \\
\hline & Italy & 24.0 & Portugal & 22.5 \\
\hline & United Kingdom & 21.8 & Germany & 22.5 \\
\hline & Belgium & 21.8 & & \\
\hline & Denmark & 21.5 & & \\
\hline \multirow{10}{*}{ II } & France & 20.8 & Spain & 20.0 \\
\hline & Greece & 20.8 & Finland & 18.8 \\
\hline & Austria & 20.0 & France & 17.8 \\
\hline & Spain & 19.3 & Lithuania & 17.8 \\
\hline & Luxemburg & 15.8 & Sweden & 17.5 \\
\hline & Portugal & 14.3 & Austria & 17.3 \\
\hline & & & Latvia & 16.3 \\
\hline & & & Estonia & 16.0 \\
\hline & & & Belgium & 15.5 \\
\hline & & & Bulgaria & 14.5 \\
\hline \multirow{10}{*}{ III } & Finland & 14.0 & Slovenia & 14.3 \\
\hline & Netherlands & 13.3 & Malta & 12.5 \\
\hline & Hungary & 12.3 & Hungary & 11.3 \\
\hline & Bulgaria & 12.0 & United Kingdom & 11.0 \\
\hline & Latvia & 11.3 & Denmark & 11.0 \\
\hline & Estonia & 10.0 & Netherlands & 9.8 \\
\hline & Czech Republic & 9.3 & Czech Republic & 8.8 \\
\hline & Lithuania & 9.0 & Poland & 7.8 \\
\hline & Cyprus & 8.5 & Romania & 7.8 \\
\hline & Slovenia & 8.3 & & \\
\hline \multirow{5}{*}{$\begin{array}{l}\text { IV } \\
\text { the youngest } \\
\text { countries }\end{array}$} & Ireland & 5.8 & Luxemburg & 7.3 \\
\hline & Malta & 5.3 & Slovakia & 3.3 \\
\hline & Romania & 4.0 & Cyprus & 3.0 \\
\hline & Poland & 3.3 & Ireland & 2.8 \\
\hline & Slovakia & 2.5 & & \\
\hline
\end{tabular}

Source: own study. 
In 1996, the following countries were included in the oldest country group (group I): Sweden, Germany, Italy, Great Britain, Belgium, Denmark, i.e. countries of the "old" Union, on the other hand, the following countries were included in the youngest country group (group IV): Slovakia, Poland, Romania, Malta, Ireland, where the youngest country was Slovakia.

In 2016, the ordering of the countries was changed, but a part of them did not change their appurtenance to the typological group. Italy and Germany remained in the group of the oldest countries, but Italy took the first position in the ranking, becoming the oldest country in the EU. Greece and Portugal joined the group of the oldest countries in 2016. In 2016, the youngest country in the Union was Ireland, next to which in Group IV were the following countries: Cyprus, Slovakia and Luxembourg. The reasons for the relatively good demographic situation of Ireland should be sought in the highest birth rate and one of the highest fertility rates among the EU Member States.

The synthetic determination of the ageing process advancement level in dynamic terms was carried out using the ageing rate $(A R)$ which provides for the concurrent changes in the number of the old and young population (fig. 6). The $A R$ ratio was determined for the period of 1999-2016 with breakdown into ten years' periods. The values of this ratio shows a significant differentiation of dynamics of population ageing processes in the particular counties. The mean Union value of the $A R$ ratio was ca. 0.07 and the range of variability was between 0.02 to 0.15 . All countries of the "new" Union, including Poland and Baltic States, were characterised with a significant ageing dynamics, exceeding the mean Union value.

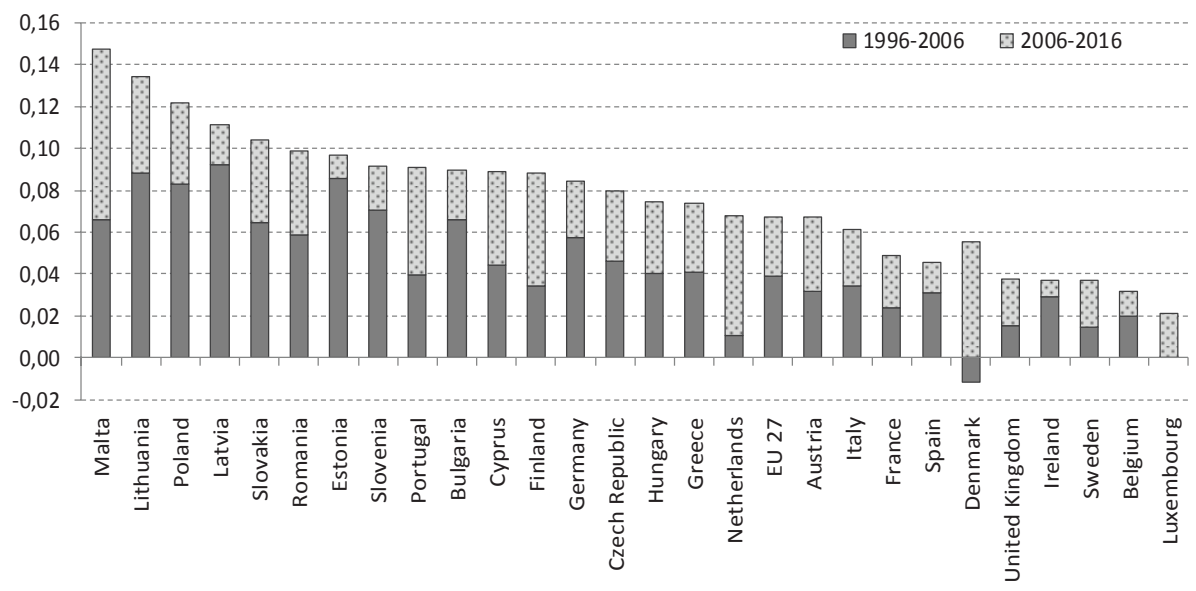

Fig. 6. The ageing rate $A R$ in the EU Member States in the period of $1996-2016$

Source: own study on the basis of Eurostat data.

In Malta, Lithuania, Poland, Latvia and Slovakia, the analysed ratio exceeded the value of 0.10 which indicates a rapid process of demographical ageing in those counties. A specifically dramatic situation can be found in Malta where this ratio reached the level of ca. 0.15 in the period of 1996-2016, with the ageing process dynamics being visibly higher in the second decade of the examined period. It should be emphasized that Malta belonged to the group of the youngest countries (group IV) in 1996, but after 20 years - in 


\section{E. Wasilewska}

a relatively short period of time, it moved in the ranking of demographical senility to a place close to the a position (table 1). In the "new" Union Member States there were exceptionally unfavourable changes in the age structure, leading to a high rate of society ageing, whereas the "old" Union Member States were generally characterised with slower ageing rates (Jakovljevic, Laaser, 2015). The counties of the lowest ageing dynamics in the period of 1996-2016 include the following: Luxembourg, Belgium, Sweden, Ireland and United Kingdom. Here, the $A R$ ratio did not exceed the value of 0.04 . The relatively low intensity of the ageing process of those counties may indicate their growing demographical potential. The reasons for the observed tendencies could be sought in the migration wave, particularly in case of young people, from the countries of the former socialist states to the remaining EU member states - with a higher level of social-economic development due to the possibility of taking up work there (Jakovljevic et al., 2016). The example of the positive influence of immigration on the demographical situation of a country is Germany which, in the sphere of natural movement, are characterised with a negative birth rate and very low levels of fertility rate, but due to the inflow of economic immigrants, its population situation was stablised effectively (Żołędowski, 2012). In relation to the counties of the "new" Union, the outflow of young people accelerates the ageing dynamics (Jakovljevic et al., 2017). The goal of the policy of such countries should be commercial activation through creation of conditions for inflow of various types of investments and offering new places of work to prevent further outflow of young people (Kurek, 2008).

\section{Summary}

1. In the period of 1996-2016, the European Union Member States were characterised with an advancing ageing process, in the countries of "old" Union, the highest level of demographical senility advancement was observed along with lower dynamics of this process than in the countries which are new members of the Community.

2. The degree of population senility advancement (in accordance to the aggregated measure) in 1996 was the highest in Sweden, while the lowest was in Slovakia. In 2016, the group of the oldest European Union countries included: Italy, Greece, Portugal, Germany The youngest countries were: Ireland, Cyprus, Slovakia and Luxembourg.

3. The highest dynamics of population ageing was observed in the countries of the "new" Union, in particular in Malta, Lithuania, Poland, Latvia and Slovakia. Quick pace of population ageing in those counties can be determined by the migration level of young people to the counties with a higher level of social-economic development due to the possibility of taking up work in those countries. The northern counties of the "old" Union were characterized with the lowest pace of ageing, including: Luxembourg, Belgium, Sweden, Ireland and United Kingdom.

4. Population ageing is a highly differentiated process in spatial terms. The current assessment of the demographical situation as well as constant monitoring of population processes can be helpful in determination and elimination of negative effects of society ageing as well as in adjustment of social-economic development aiding tools at the scale of a nation as well as in the local and regional dimension (Jakovljevic et al., 2017). 


\section{References}

Blaikie, A. (1999). Ageing and popular culture. Cambridge University Press, Cambridge.

Buchanan, P.J. (2010). The death of the West: How dying populations and immigrant invasions imperil our country and civilization. Macmillan. New York.

Cieślak, M. (1992). Demografia. Metody analizy i prognozowania. Wydawnictwo Naukowe PWN, Warszawa.

Coulmas, F. (2007). Population decline and ageing in Japan-the social consequences. Routledge, London.

Gierańczyk, W., Sadoch, A. (2016). Starzenie się ludności w miastach województwa kujawsko-pomorskiego w świetle prognozy demograficznej do 2050 r. In: Starzenie się ludności jako wyzwanie XXI wieku. Ujęcie interdyscyplinarne, Gierańczyk W. (ed.) Wyższa Szkoła Bankowa w Toruniu, Toruń, 31-48.

Eurostat (2017). Accessed October 2017 from: http://ec.europa.eu/eurostat/data/database.

Jakovljevic, M. (2015). The aging of Europe. The unexplored potential. Farmeconomia. Health Economics and Therapeutic Pathways, 16(4), 89-92, http://dx.doi.org/10.7175/fe.v16i4.

Jakovljevic, M., Arsenijevic, J., Pavlova, M., Verhaeghe, N., Laaser, U., Groot, W. (2017) Within the triangle of healthcare legacies: comparing the performance of South-Eastern European health systems. Journal of Medical Economics, 20(5), 483-492.

Jakovljevic, M., Laaser, U. (2015). Population aging from 1950 to 2010 in seventeen transitional countries in the wider region of South Eastern Europe (Original research). SEEJPH, posted: 21 February 2015. Accessed December 2017 from: https://papers.ssrn.com/sol3/papers.cfm?abstract id=2725386.

Jakovljevic, M., Romeu-Gordo, L., Vukovic, M., Krstic, M. (2017). Gender-Specific Health-Seeking Behavior and Income Status among the Elderly Citizens of Serbia. Eastern European Business and Economics Journal, 3(1), 67-86.

Jakovljevic, M., Vukovic, M., Fontanesi, J. (2016). Life Expectancy and Health Expenditure Evolution in Eastern Europe - DiD and DEA analysis. Expert Reviews in Pharmacoeconomics and Outcomes Research, 16(4), 537-546.

Jurek, Ł. (2012). Ekonomia starzejącego się społeczeństwa. Wydawnictwo Difin SA, Warszawa.

Kłos, B., Russel, P. (eds.) (2016). Przemiany demograficzne w Polsce i ich społeczno-ekonomiczne konsekwencje. Wydawnictwo Sejmowe, Warszawa.

Kowaleski, J.T. (2011). Przestrzenne zróżnicowanie starzenia się ludności Polski. Przyczyny, etapy, następstwa. Wydawnictwo Uniwersytetu Łódzkiego, Łódź.

Kowaleski, J.T., Majdzińska, A. (2012). Starzenie się populacji krajów Unii Europejskiej - nieodległa przeszłość i prognoza. Studia Demograficzne, 1 (161), 57-80.

Król, M. (2014). Starzenie się populacji Polski. In: Współczesna polityka gospodarcza i społeczna. Przegląd Nauk Stosowanych nr 4, Król M. (ed.). Gliwicka Wyższa Szkoła Przedsiębiorczości, Gliwice, 9-21.

Kurek, S. (2008). Typologia starzenia się ludności Polski w ujęciu przestrzennym. Wydawnictwo Naukowe Akademii Pedagogicznej, Prace Monograficzne nr 497, Kraków.

Kurkiewicz, J. (ed.) (2010). Procesy demograficzne i metody ich analizy. Wydawnictwo Uniwersytetu Ekonomicznego w Krakowie, Kraków.

Malina, A. (2004). Wielowymiarowa analiza przestrzennego zróżnicowania struktury gospodarki Polski według województw. Wydawnictwo Akademii Ekonomicznej w Krakowie, Kraków.

Malina, A., Wanat, S. (1995). Przestrzenna analiza rozwoju Polski. Wiadomości Statystyczne, 5, 20-25.

Ogura, S., Jakovljevic, M. (2014). Health financing constrained by population aging - an opportunity to learn from Japanese experience. Serbian Journal Experimental and Clinical Research, 15 (4), 175-181.

Okólski, M. (2004). Demografia. Wydawnictwo Naukowe Scholar, Warszawa.

Panek, T., Zwierzchowski, J. (2013). Statystyczne metody wielowymiarowej analizy porównawczej. Teoria i zastosowania. Oficyna Wydawnicza Szkołą Główna Handlowa w Warszawie, Warszawa.

Rakowska, J. (2016). Analysis of the degree of population ageing in Poland on LAU2 Level. Economic and Regional Studies, 9(2), 13-23.

The 2018 Ageing Report. Underlying Assumptions and Projection Methodologies (2017). Institutional Paper 065 , Publications Office of the European Union, Luxembourg. Accessed December 2017 from: https:/ec.europa.eu/info/publications/economy-finance/2018-ageing-report-underlying-assumptions-andprojection-methodologies en.

Urbaniak, B., Gładzicka-Janowska, A., Żyra, J., Kaliszczak, L., Piekutowska, A., Rollnik-Sadowska, E., Sobolewska-Poniedziałek, E., Niewiadomska, A., Gagacka M. (2015). Socjoekonomika starzenia się współczesnych społeczeństw. Wydawnictwo CeDeWu, Warszawa.

Żołędowski, C. (2012). Starzenie się ludności - Polska na tle Unii Europejskiej. Instytut Polityki Społecznej, Uniwersytet Warszawski, Warszawa. 